\title{
Comparison of the Application of Corporate Social Responsibility in Indonesia and United Kingdom
}

\author{
Paulus Aluk Fadjar Dwi Santo ${ }^{1}$, Muhammad Farhan Akmal ${ }^{2}$ \\ \{paulus_afds@binus.edu ${ }^{1}$, muhammad.akmal@binus.ac.id ${ }^{2}$ \} \\ Binus University, Indonesia ${ }^{1,2}$
}

\begin{abstract}
This study uses the comparative law method, Indonesia Law Number 40 of 2007 and United Kingdom Companies Act 2006 as the main studies. The aim of the study is to show the implementation of CSR in Indonesia compared to UK. From the research, it can be concluded that awareness of the importance of CSR must be built in Indonesia, so the CSR becomes effective, on target, and beneficial. The application can be learned from the UK, which has made private companies aware of the importance of CSR as they believe CSR can bring benefits in the future.
\end{abstract}

Keywords: Corporate Social Responsibility, Indonesia, UK, Indonesian Limited Liability Companies Law, Companies Act 2006

\section{Introduction}

The concept of CSR was formed around the world to be precise more than 60 years ago [1]. CSR thinking is that business companies have a responsibility to society in addition to aiming for profit [2]. According to the United Nations Industrial Development Organization, CSR is management concept whereby companies integrate social and environmental concerns in their business operations and interactions with their stakeholders [3]. In the development of CSR, the European Community Commission states that there are 4 factors that encourage the development of CSR, namely the existence of new concerns and hopes in the context of globalization and large-scale industry, social influence in making decisions in terms of investment, concern for environmental damage due to economic activity, development of communication technology in business activities [4].

Therefore, the concept of CSR has the potential and can be a useful tool to empower the community. Then, companies as private parties can aid the government as state administrators to increase the quality of human resources and protect the natural resources around them. In fact, CSR activities can prevent a crisis for a corporation if they are conducted with professionalism, sincerity, sustainability, and good management [4]. However, CSR will become a new potential problem or even have a negative impact on the surrounding community and the environment if its implementation fails the target. Therefore, here the researchers try to examine the implementation of CSR in Indonesia and the UK to compare the ecosystem and the implementation of CSR in both countries, which will later aim to provide suggestions on how to implement CSR, especially in Indonesia. 


\section{Research Methods}

Method as an approach to this writing uses comparative laws. This is necessary to understand the origin of the idea of CSR and how this value is developed and practiced in Indonesia. Furthermore, the main principle is to compare the regulations covering CSR practices in the two countries. According to Tahir Tungadi, as quoted by Soeroso, legal comparisons can be used for:

1) Descriptive Comparative Law, which provides a descriptive illustration of how a legal rule is regulated in various legal systems without any further analysis.

2) Applied Comparative Law, which uses the results of descriptive legal comparisons to choose which of the legal institutions under study is the best and suitable to be applied. This method is used for the benefit of legislative institutions for drafting bills, by lawyers and notaries for contract drafting, by judges to make appropriate decisions, or by governments to make fair decisions.

3) Comparative History of Law related to the history of sociology of law, anthropology of law and philosophy of law.

4) Modern legal comparisons have used critical, realistic and undogmatic methods. Critical means do not only concern on the differences or similarities of various legal systems, realistically means that legal comparisons are not only examining legislation, court decisions or doctrines, not meaningful dogmatically because legal comparisons do not want to be confined in the rigidity of dogmas as is often the case in every legal system [5]. The purpose is to provide knowledge about the similarities and differences between various fields and legal systems, as well as the understanding and basis of the legal system. With this understanding, it will be easy to carry out unification, legal certainty, and legal simplification. The results of comparative law will be useful for the application of law in society, especially to find out which areas of law can be unified and which fields must be regulated by law between legal systems [6].

From the four models above, the authors mostly use modern legal comparison methods to answer problems related to the reconceptualization of CSR in Indonesia.

\section{Discussion}

\subsection{CSR in UK}

\subsubsection{Terms of Implementation of CSR in UK}

Corporate Social Responsibility (CSR) is an integration of environmental, social, economic into business strategy and practice [7]. CSR was discussed more than half a century ago, and emerged after the Industrial Revolution by visionary business leaders in Great Britain in the $19^{\text {th }}$ century [8]. Business leaders at that time realized that business has a responsibility to the society, as seen by the existence of factory towns such as Bourneville and Port Sunlight which were aimed at facilitating workers and their families [8]. The understanding of CSR is based on the fact that business activities are the basis of society, which presents a challenge for organizations to clearly demonstrate the company's business ethics, and recognize the desires of business leaders and combine them to make a beneficial contribution to society [9]. In the UK, the history 
of CSR began in 1600 when the English East India Company was founded in the UK, until it was developed to the modern CSR concept that exists today [10]. Although in the UK there are no specific regulations governing CSR, there are regulations that give the company the responsibility to carry out CSR [11]. One of the provisions regarding CSR in the UK can be seen through the Company Act 2006 as follows:

172

Duty to promote the success of the company

(1) A director of a company must act in the way he considers, in good faith, would be most likely to promote the success of the company for the benefit of its members as a whole, and in doing so have regard (amongst other matters) to:

(a) the likely consequences of any decision in the long term;

(b) the interests of the company's employees;

(c) the need to foster the company's business relationships with suppliers, customers and others;

(d) the impact of the company's operations on the community and the environment;

(e) the desirability of the company maintaining a reputation for high standards of business conduct; and

(f) the need to act fairly as between members of the company.

(2) Where or to the extent that the purposes of the company consist of or include other purposes than the benefits of its members, subsection (1) has effect as if the reference to promote the success of the company for the benefits of its members were to achieve those purposes.

(3) The duty imposed by this section has effect subject to any enactment or rule of law requiring directors, in certain circumstances, to consider or act in the interests of creditors of the company.

If we look at the article above, the emphasis on CSR is given to companies to run the company in good faith by paying attention to the interests of employees and the company's operations must have a positive impact on the surrounding community and the environment.

\section{8}

Civil Consequences of breach of general duties

(1) The consequences of breach (or threatened breach) of sections 171 to 177 are the same as would apply if the corresponding common law rule or equitable principle applied.

(2) The duties in those sections (with the exception of section 174 (duty to exercise reasonable care, skill and diligence)) are, accordingly, enforceable in the same way as any other fiduciary duty owed to a company by its directors.

Based on the article above related to legal consequences or civil sanctions, it is also applied if CSR provisions are not carried out with reference to the principles of balance and fairness.

\section{7}

Contents of directors' report: business review

(1) Unless the company is subject to the small companies 'regime, the directors' report must contain a business review. 
(2) The purpose of the business review is to inform members of the company and help them assess how the directors have performed their duty under section 172 (duty to promote the success of the company).

(3) The business review must contain-

(a) a fair review of the company's business; and

(b) a description of the principal risks and uncertainties facing the company.

(4) The review required is a balanced and comprehensive analysis of -

(a) he development and performance of the company's business during the financial year; and

(b) the position of the company's business at the end of that year, consistent with the size and complexity of the business.

(5) In the case of a quoted company the business review must, to the extent necessary for an understanding of the development, performance or position of the company's business, include:

(a) the main trends and factors likely to affect the future development, performance and position of the company's business; and

(b) information about;

(i) environmental matters (including the impact of the company's business on the environment);

(ii) the company's employees; and

(iii) social and community issues, including information about any policies of the company in relation to those matters and the effectiveness of those policies.

(c) subject to subsection (11), information about persons with whom the company has contractual or other arrangements which are essential to the business of the company. If the review does not contain information of each kind mentioned in paragraphs (b) (i), (ii) and (iii) and (c), it must state which of those kinds of information it does not contain.

(6) The review must, to the extent necessary for an understanding of the development, performance or position of the company's business, include:

(a) analysis using financial key performance indicators; and

(b) where appropriate, analysis using other key performance indicators, including information relating to environmental matters and employee matters. "Key performance indicators" means factors by reference to which the development, performance or position of the company's business can be measured effectively.

(7) Where a company qualifies as medium-sized in relation to a financial year (see sections 465 to 467), the directors' report for the year need not comply with the requirements of subsection (6) so far as they relate to non-financial information.

The article above reflects that the Board of Directors must create a good business action report and it must cover environmental problems (including the impact of the company's business on the environment), company employees, and social and community issues.

\subsubsection{CSR Implementation in the UK}

There are previous studies examining the implementation of CSR in the UK, although this study does not represent companies in the UK as a whole, it can provide an overview of the practices of several companies in the UK. Research shows that in the UK CSR is not part of the 
vision and mission of companies, where the vision and mission of their company focuses on the basic value of their efforts to satisfy shareholders [12]. However, they continue their activities as agents of economic and social development because of their concern and awareness of the importance of CSR [12]. The reasons for companies in the UK to carry out CSR are more than just required by law, namely because of the awareness to uphold ethics, and they believe that CSR can provide economic benefits in the future [12]. It is reasonable to say because in the UK there are companies that try to give a different approach in the market, and make CSR a means to promote their brands so that they get recognition in the community [12]. CSR provides other benefits such as providing positive reactions from clients, new business opportunities, dedication, loyalty and respect from workers in the company [12].

In the UK, in general, the application of CSR has a focus on business projects in the financial sector, such as through the distribution of investment funds [1]. In addition, information related to CSR includes weekly publications and information, which make CSR implementation transparent [1]. Government involvement in CSR development is manifested by the government's pro-active role in creating partnerships with stakeholders [1].

\subsection{CSR in Indonesia}

\subsubsection{CSR Provisions in Indonesia}

CSR are regulated normatively through Law No. 40 of 2007 on Limited Liability Companies, Law No. 25 of 2007 on Investment, and other laws and regulations as follows:

Table 1. CSR Regulations in Indonesia

Law No. 40 of 2007 Article 1 point 3:

concerning Limited Social and Environmental Responsibility shall be a commitment Liability Companies of Corporation to take parts in sustainable economic development in order to develop life quality and beneficial environment either for a Corporation itself or site community or public.

\section{Article 74}

(1) A Corporation operating business activity in the field and/or related with natural resources shall be obliged to implement social and environmental responsibilities;

(2) Social and environmental responsibilities as referred to in paragraph (1) shall be obligation of Corporation that is budgeted and calculated as expenses of Corporation that its implementation is conducted by considering compliance and regularity;

(3) A Corporation that does not implement its obligation as referred to in paragraph (1) shall be imposed with sanction in accordance with prevailing laws and regulation;

(4) Further provision on Social and Environmental Responsibilities shall be governed in Government Regulation.

Law No. 25 of 2007 on Article 15

Investment Every investor shall have obligations:

a. to apply the principle of good corporate governance;

b. to implement corporate social responsibility; 


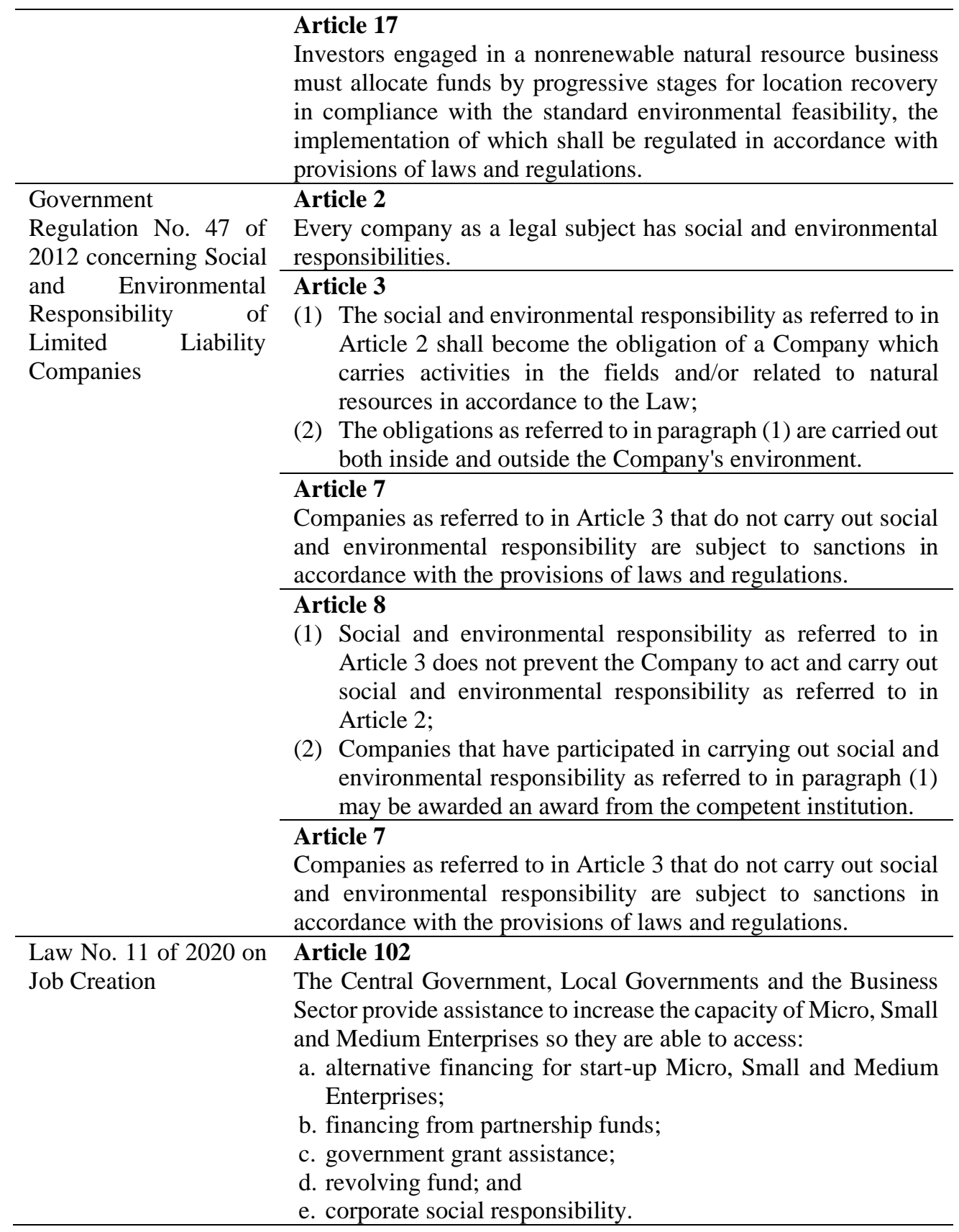

Based on the above explanation, it illustrates that there are obligations to concern and conduct CSR activities aimed at companies in Indonesia. Moreover, companies which do not implement CSR properly will be sanctioned in accordance with the applicable laws. However, CSR is only strictly required in the law only for companies related to foreign investment, companies related to natural resources, and companies that are specifically regulated by 
ministerial regulations. So that there is no obligation for companies that are outside the categories as stated in the law to concern or conduct CSR activities.

\subsubsection{CSR Implementation in Indonesia}

In Indonesia, CSR implementation has various problems to be fixed related to CSR activies. The concept of CSR in Indonesia depends on the company itself and is not integrated into broad development plans and tends to fail on target [13]. In fact, the concept of implementing CSR itself is based on the pro-actively partnership responsibility of all stakeholders [14]. This is different from the concept of corporate philanthropy which does not involve a socially responsible corporate partnership [14]. The implementation of CSR in Indonesia prioritizes fulfilling the desires of the community rather than the needs of the community, this is because companies do not understand the importance of implementing CSR properly [13]. As a result, CSR at this time creates a new problem, namely forming the personality of the society to become dependent on the companies [13]. The issue of CSR that was not on target was revealed by the Minister of Women Empowerment and Child Protection in 2015, Yohana Yembise, who said that the estimated CSR funds in Indonesia which reached Rp 12 trillion a year had not been properly optimized for community empowerment [15]. Therefore, according to the researchers' opinion, socialization and comprehensively regulation related CSR are needed, especially related to forms of CSR that must be carried out by companies so the goals of CSR are achievable.

Then in the implementation of CSR also has various problems especially from social disparities between business actors and the society, corruption, and the company's failure to understand the needs of the surrounding community which triggers conflict [15]. Especially if the company is a foreign company whose country of origin is identical to a certain religion, potentially it can shape the society's sentiments and perspectives [16]. The existence of this social problem actually supports the opinion of Raharjo, which states that society is not just an economic entity but must be seen sociologically [16]. Thus, to make CSR activities on target and companies get social recognition, it needs the ability to understand society comprehensively and not only have or give an economic impact. Moreover, Indonesia is consisting of various ethnicities, cultures, religions, races and languages which makes each region have different characteristics of society. According to the BPS' data (Indonesian Central Bureau of Statistics) in 2010, Indonesia has more than 300 ethnic groups, more precisely there are 1,340 ethnic groups in the country [17].

\subsubsection{Comparison of CSR Implementation in Indonesia and UK}

Based on the above examination and explanation, it can be concluded that firstly, public awareness of CSR in the UK is superior than in Indonesia. Awareness and knowledge of the positive impact of CSR which can provide benefits both economically and socially makes companies in the UK not need to be obligated to carry out CSR, the reason is because there are community values that uphold ethics and a sense of volunteerism. Legal regulations in the UK are only a means of ensuring CSR implementation. The UK government itself makes efforts and approaches to increase public awareness of the importance of CSR which can be emulated or imitated in Indonesia. In Indonesia implementation of CSR in Indonesia has various problems ranging from corruption, horizontal conflicts, social disparities, fails to achive the target and so on. CSR practices in Indonesia are deemed to have failed on target and instead make people dependent on a company and become not empowered. In contrast to the UK, which has carried 
out CSR which can empower people in the form of access to capital and have stronger partnerships between stakeholders. Then, the Companies Act 2006 in the UK covers all existing companies while Indonesian regulations emphasize CSR obligations only to companies that have activities related to natural resources, investment, and companies which are governed by minister regulations. Therefore, it requires the role of all stakeholders in Indonesia to collaborate to build awareness and work together as social beings to have a positive impact on the environment and surrounding communities. Reminding that CSR not only has a positive impact on society and the environment, but also has a positive impact for the corporation itself.

\section{Conclusion}

The Indonesian government can learn from the UK in terms of creating a CSR ecosystem which is conducted through a partnership, transparently and on target, and by good management. The main focus is to pro-actively create partnerships and embrace all stakeholders, conduct socialization or make regulations regarding forms of CSR so that the community becomes empowered and not dependent on the company. CSR regulations must be changed and not only emphasized for certain related companies, but reach out to all companies. This is in purpose to increase the number of companies participating in integrated CSR programs so they can contribute to national development properly. Moreover it can make companies in Indonesia harmonize with the surrounding community so that business activities can perfectly going fine.

\section{Acknowledgment}

This research is conducted without any grants, incentives, and/or funding from any party.

\section{References}

[1] F. Madrakhimova, "History of development of corporate social responsibility," J. Bus. Econ. USA Acad. Star Publ. Co., vol. 4, no. 6, pp. 509-520, 2013.

[2] A. B. Carroll and K. M. Shabana, "The business case for corporate social responsibility: A review of concepts, research and practice," Int. J. Manag. Rev., vol. 12, no. 1, pp. 85-105, 2010.

[3] United Nations Industrial Development Organization, "What is CSR?," United Nations Industrial Development Organization. [Online]. Available: https://www.unido.org/our-focus/advancingeconomic-competitiveness/competitive-trade-capacities-and-corporate-responsibility/corporatesocial-responsibility-market-integration/what-csr\#: :text=CSR is generally understood as,expectations of shareholders and stakeholders.

[4] R. Rahman, Corporate social responsibility: Antara teori dan kenyataan. Medpress, 2009.

[5] R. Soeroso, "Perbandingan Hukum Perdata. cet ke 7," Jakarta Sinar Graf., 2007.

[6] S. Soekanto, Pengantar penelitian hukum. Penerbit Universitas Indonesia (UI-Press), 2006.

[7] P. Jones, D. Comfort, and D. Hillier, "Corporate social responsibility and the UK construction industry," J. Corp. Real Estate, 2006.

[8] N. C. Smith, "Corporate social responsibility: whether or how?," Calif. Manage. Rev., vol. 45, no. 4, pp. 52-76, 2003.

[9] T. Breitbarth and P. Harris, "The role of corporate social responsibility in the football business: Towards the development of a conceptual model," Eur. Sport Manag. Q., vol. 8, no. 2, pp. 179206, 2008. 
[10] S. O. Idowu, "An exploratory study of the historical landscape of corporate social responsibility in the UK," Corp. Gov. Int. J. Bus. Soc., 2011.

[11] Pinsent Masons, "Corporate Social Responsibility the UK Corporate Governance Code," Pinsent Masons. [Online]. Available: https://www.pinsentmasons.com/out-law/guides/corporate-socialresponsibility--the-uk-corporate-governance-code.

[12] D. U. Duman, H. Giritli, and P. McDermott, "Corporate social responsibility in construction industry: A comparative study between UK and Turkey," Built Environ. Proj. Asset Manag., 2016.

[13] G. B. Nayenggita, S. T. Raharjo, and R. Resnawaty, "Praktik corporate social responsibility (csr) di Indonesia," Focus J. Pekerj. Sos., vol. 2, no. 1, pp. 61-66, 2019.

[14] B. Rudito and M. Famiola, "CSR (Corporate Social Responsibility)," 2013.

[15] Antaranews.com, "Rp. 12 Triliun Dana CSR Indonesia belum dikelola maksimal," ANTARANews.com. [Online]. Available: https://www.antaranews.com/berita/509654/rp12triliun-dana-csr-indonesia-belum-dikelola-maksimal.

[16] S. T. Raharjo, Relasi dinamis antara perusahaan dengan masyarakat lokal: kajian mengenai kegiatan tanggung jawab sosial industri geothermal kepada masyarakat lokal. Unpad Press, 2013.

[17] Administrator, "Suku Bangsa," Portal Informasi Indonesia. [Online]. Available: https://indonesia.go.id/profil/suku-bangsa/kebudayaan/suku-bangsa. 